\title{
SENAM AEROBIK INTENSITAS SEDANG MENURUNKAN KADAR KOLESTEROL TOTAL DAN INDEKS MASSA TUBUH WANITA PENDERITA OBESITAS
}

\author{
Oleh \\ Agus Salim Samosir ${ }^{1}$, Fajar Apollo Sinaga ${ }^{1 *}$, Jumadin IP$^{1}$, Rika Nailuvar Sinaga ${ }^{1}$, \\ Deni Rahman Marpaung ${ }^{1}$. \\ ${ }^{1}$ Fakultas Ilmu Keolahragaan, Universitas Negeri Medan \\ Email: sinagafajar@yahoo.com
}

\begin{abstract}
Abstrak
Prevalensi obesitas dari tahun ke tahun mengalami peningkatan yang dapat membahayakan kesehatan terutama penyakit cardiovascular yang ditandai dengan peningkatan Indeks Massa Tubuh (IMT) dan kadar kolesterol. Tujuan penelitian adalah untuk mengetahui pengaruh senam aerobik intensitas sedang terhadap penurunan Indeks Massa Tubuh dan kadar total kolesterol pada wanita penderita obesitas. Jenis penelitian adalah penelitian eksperimental semu dengan rancangan penelitian one group pretest postets design. Sampel penelitian berjumlah 10 orang yang sudah memenuhi kriteria. Senam aerobik dilakukan selama satu bulan, 3 kali seminggu, waktu 50 menit dengan target denyut jantung 60-70\% MHR. Pengukuran IMT dan kolesterol total dilakukan sebelum dimulai program latihan dan setelah dan setelah menjalani program latihan senam aerobik. Hasil penelitian diperoleh IMT dan kadar kolesterol total pretest adalah $39,61 \mathrm{~kg} / \mathrm{m}^{2}$ dan $191,1 \mathrm{mg} / \mathrm{dl}$. Kadar IMT dan kadar kolesterol total postest adalah $24,81 \mathrm{~kg} / \mathrm{m}^{2}$ dan $154 \mathrm{mg} / \mathrm{dl}$. Hasil uji statistika menunjukkan terdapat perbedaan IMT dan kadar total kolesterol pretest dan postest. Kesimpulan penelitian adalah senam aerobik intensitas sedang dapat menurunkan IMT dan kadar kolesterol total pada wanita penderita obesitas.
\end{abstract}

Kata kunci: Senam aerobik, Intensitas sedang, Indeks massa tubuh, Kolesterol

\section{A. PENDAHULUAN}

Obesitas atau kegemukan merupakan masalah yang muncul pada beberapa dekade terakhir ini. WHO menggambarkan pada tahun 2016, lebih dari 1,9 miliar orang dewasa mengalami kelebihan berat badan. Dari jumlah ini, lebih dari 650 juta orang mengalami obesitas. Kegemukan dan obesitas didefinisikan sebagai akumulasi lemak abnormal atau berlebihan yang dapat merusak kesehatan (WHO, 2017)

Kelebihan berat badan (over weight) dan obesitas terjadi karena kalori yang di dapat dari bahan makanan lebih besar dari kalori yang dipakai untuk kegiatan yang di lakukan sehari-hari dan terjadi dalam waktu yang cukup lama dan biasanya kelebihan kalori ini di simpan dalam tubuh dalam bentuk lemak (trigliserida).

Pada umumnya wanita memiliki persentase lemak badan yang lebih banyak dibandingkan pria. Perbandingan yang normal antara persentase lemak badan dengan 
berat badan adalah $25-30 \%$ pada wanita dan $18-23 \%$ pada pria (Wellness, 1994). Lemak berguna bagi tubuh, namun jika jumlahnya berlebihan cenderung menimbulkan penyakit. Wanita dengan lemak tubuh lebih dari $30 \%$ dan pria dengan lemk tubuh lebih 25\% dianggap mengalami obesitas (Ismaryati, 2008). Kelebihan lemak adalah kenyataan yang dapat memici terjadinya banyak penyakit. Meningkatnya kolesterol dalam darah memicu penyempitan atau penyumbatan pembuluh darah di otak, penyempitan pada pembuluh darah di jantung yang dapat menyebabkan penyakit kardiovascular (Nila, 2008).

Penyakit kardiovaskular merupakan penyakit dengan proporsi tertinggi angka kematian penyakit tidak menular (PTM). Hal ini sesuai dengan data World Health Organization (WHO) tahun 2016 yang menyebutkan bahwa 56 juta kematian diseluruh dunia, 38 juta diantaranya disebabkan oleh PTM dan proporsi penyebab utama kematian PTM pada tahun 2016 itu diantaranya: penyakit kardiovaskular (37\%), kanker (27\%), penyakit pernapasan $(8 \%)$ dan diabetes (4\%). Selanjutnya WHO juga melaporkan bahwa kematian karena penyakit kardiovaskular tersebut 7,4 juta disebabkan oleh penyakit jantung koroner dan sebesar 6,7 juta orang disebabkan oleh stroke (WHO, 2016).

Lemak tubuh yang berlebihan dan obesitas dapat menimbulkan faktor resiko terhadap diabetes, penyakit kardiovaskular, dan dislipidemia (Pratiwi, 2010). Kolesterol total termasuk salah satu indikator untuk menentukan risiko penyakit kardiovaskular. Hiperkolesterolemia atau peningkatan kadar kolesterol total umumnya tidak menimbulkan gejala, sehingga pemeriksaan untuk pencegahan dan pemeriksaan rutin kadar kolesterol diperlukan sebagai tindakan pencegahan bagi individu yang beresiko tinggi (Shah dkk., 2008).

Studi menunjukkan, penambahan berat badan diiringi pula dengan peningkatan serum kolesterol. Setiap peningkatan $1 \mathrm{~kg} / \mathrm{m} 2$, indeks massa tubuh (IMT) berhubungan dengan kolesterol total plasma 7,7 mg/dl dan penurunan HDL 0,8 mg/dl. Selain itu juga, studi menunjukkan obesitas menyebabkan angka sintesis kolesterol endogen sebanyak $20 \mathrm{mg}$ setiap hari untuk setiap kilogram kelebihan berat badan, peningkatan sintesis VLDL dan produksi trigliserida (Laurentia, 2012).

Berdasarkan data Departemen Kesehatan RI (2013) mengenai riset kesehatan dasar, prevalensi obesitas (IMT> 25) pada laki-laki dan perempuan dewasa (>18 tahun) 
terus mengalami peningkatan setiap tahunnya. Pada tahun 2013 ditemukan prevalensi obesitas pada laki-laki sebanyak 19,7\% dan perempuan sebanyak 32,9\%.

Di Indonesia angka kejadian hiperkolesterolemia menurut penelitian MONICA I (Multinational Monitoring of Trends Deter minantsin Cardiovascular Diseases) sebesar 13,4\% untuk wanita dan 11,4\% untuk pria. Pada MONICA II terjadi peningkatan sebesar 16,2\% untuk wanita dan $14 \%$ untuk pria. Wanita menjadi kelompok paling banyak menderita masalah ini yakni $14,5 \%$ atau hampir dua kali lipat kelompok lakilaki (Linawati, 2011). Beberapa penelitian telah membuktikan bahwa pria dan wanita dari berbagai kelompok umur mengalami kenaikan kadar kolesterol total dengan meningkatnya Indeks Massa Tubuh (Ecol, 2008). Hiperkolesterolemia telah dikonfirmasi sebagai faktor risiko independen untuk aterosklerosis dan trombosis, penyakit jantung koroner dan stroke iskemik (Saeed, 2015).

Lemak (trigliserida) endogen merupakan cadangan energi (bahan bakar) yang paling besar yang terdapat di dalam tubuh. Kebanyakan trigliserida (lemak) disimpan pada jaringan adiposa (jaringan lemak) $\approx 17.500 \mathrm{mmol}$ pada orang dewasa). Selain itu Trigliserida juga terdapat pada otot skelet $(\approx 300 \mathrm{mmol})$ dan pada plasma $\approx 0.5 \mathrm{mmol}$. Total jumlah energi yang tersimpan sebagai trigliserida $\approx 560$ MJ. Jumlah ini lebih besar 60 kali lebih besar jika dibandingkan dengan jumlah glikogen $(\approx 9 \mathrm{MJ})$ yang tersimpan sebagai cadangan energi. Penggunaan asam lemak sebagai sumber energi memerlukan hidrolisis (lipolisis) trigliserida dari jaringan lemak, otot, dan plasma (Jeffrey F H dan Samuel K, 2000).

Trigliserida (lemak) endogen yang disimpan dalam jaringan adiposa (jaringan lemak) dan otot adalah merupakan sumber bahan bakar yang penting untuk keaktifan otot selama latihan. Intensitas latihan yang moderat akan menyebabkan proses lipolisis (trigliserida menjadi asam lemak)meningkat 2-3 kali lipat, dimana asam lemak yang dilepaskan akan dibawa darah ke otot skelet (Mora, 2000, Bettina M,2003)

Dalam rangka pemeliharaan berat badan seseorang supaya ideal, energi yang dikonsumsi harus sama dengan energi yang dikeluarkan dimana ketika ini sama maka terdapat kesetimbangan energi. Maka dalam rangka untuk menurunkan berat badan maka kesetimbangan energi ini perlu disesuikan, dimana latihan fisik memegang peranan (Marra et al., 2005). Hal-hal yang perlu diperhatikan dalam menurunkan berat badan melalui latihan fisik adalah lama latihan (durasi), intensitas, dan jenis latihan. 
Peningkatan penggunaan trigliserida (lemak) endogen sebagai sumber energi selama latihan fisik menguntungkan untuk menurunkan deposit lemak pada jaringan adiposa (William, 1998). Upaya untuk mendapatkan dosis latihan awal program latihan fisik yang efektif untuk menurunkan obesitas dengan parameter Indeks Massa Tubuh persentase lemak tubuh, penurunan kadar kolesterol salah satunya dengan melakukan latihan fisik aerobik misalnya dengan menggunakan treadmil, senam aerobik, atau ergocycle.

Menurut (Tremblay dkk, 1994 dan Aggel-Leijssen dkk, 2002) intervensi melalui latihan aerobik merupakan suatu komponen penting untuk menurunkan berat badan, dan biasanya dimasukkan sebagai bagian dari suatu program manajemen untuk menurunkan berat badan. Tetapi masih terdapat kontroversi intensitas latihan mana yang paling berpengaruh terhadap penurunan berat badan (Indeks Masssa Tubuh), trigliserida, total kolesterol, Low density lipoprotein (LDL) dan High Density Lipoprotein (HDL) apakah latihan dengan intensitas tinggi atau intensitas rendah.

Tujuan penelitian adalah untuk mengetahui pengaruh senam aerobik intensitas sedang terhadap penurunan kadar kolesterol total pada wanita penderita obesitas.

\section{B. METODOLOGI PENELITIAN/ METODE PENELITIAN}

1. Lokasi dan waktu penelitian

a. Lokasi penelitian dilakukan di J1. Bromo No. 29, Kel. Binjai, Kec. Medan Denai, Binjai, Medan Denai, Binjai, Medan Denai, Kota Medan, Sumatera Utara 20228, Indonesia

b. Waktu penelitian dilakukan pada bulan September sampai Oktober 2018

2. Bahan dan Alat Penelitian

a. Bahan penelitian diantaranya:

- larutan EDTA 1\%,

- aquadest.

- Serum darah

b. Alat penelitian diantaranya

- Hematology analizer

- Spuit,

- Kapas

- Alkohol \& Sarung tangan 


\section{Subjek Penelitian}

Subjek penelitian adalah karyawati Universitas Terbuka Medan yang berjumlah 10 orang dengan kriteria jenis kelamin perempuan, memiliki IMT $>25$ (obesitas), bersedia menjadi subjek penelitian, sehat, tidak merokok dan mengkonsumsi obat-obatan Kriteria eksklusi adalah berdasarkan pemeriksaan kesehatan mempunyai riwayat penyakit kardiovaskuler, mempunyai riwayat asma bronchial, osteoarthritis.

4. Variabel Penelitian

a. Variabel bebas yaitu senam aerobik dengan sedang.

b. Variabel terikat yaitu kadar total kolesterol dan IMT

5. Definisi Operasional Variabel

a. Senam aerobic adalah senam yang diiringi dengan bit musik dilakukan selama 50 menit frekwensi 3xseminggu, selama 1 bulan

b. Kolesterol total adalah kadar keseluruhan kolesterol yang beredar dalam tubuh yang dapat diukur dengan menggunkan alat hematology analizer

c. Berat badan adalah massa tubuh yang meliputi otot, tulang, lemak, cairan tubuh dan lain-lain yang diukur drngan timbangan digital omron body fat analyzer yang sudah terstandarisasi dan dengan tingkat ketelitian 100 gram. Penimbangan dilakukan dengan melepas sepatu Pembacaan dalam kilogram. Skala: rasio 3.

d. Tinggi badan adalah pengukuran dari lantai sampai puncak kepala pada posisi tegak sempurna diukur dengan microtoise yang sudah distandarisasi dengan ketelitian $0,1 \mathrm{~cm}$. Pengukuran dilakukan dalam posisi tegak, muka menghadap ke depan, tanpa alas kaki. Skala: rasio.

e. Indeks massa tubuh adalah penilaian status gizi dengan Indeks Massa Tubuh yaitu ukuran berat disesuaikan untuk tinggi, dihitung sebagai berat dalam kilogram dibagi dengan kuadrat tinggi dalam meter $(\mathrm{kg} / \mathrm{m} 2)$.

\section{Pelaksanaan Penelitian}

Penelitian menggunakan 10 orang wanita yang menderita obesitas. Semua sampel dilakukan pengukuran Tinggi Badan, Berat Badan dan pemeriksaan hematologi untuk mengukur kadar kolesterol total. Selanjutnya sampel melakukan latihan aerobik dengan intensitas sedang sebanyak 3 kali seminggu selama 1 bulan. Selanjutnya semua sampel dilakukan kembali pengukuran IMT dan hematology untuk mengukur kadar kolesterol total (Post test). 
a. Latihan aerobik

Latihan aerobik mengikuti bit musik yang digunakan dengan target denyut jantung 60-70\% MHR dengan durasi 50 menit. Frekuensi yang digunakan adalah 3x dalam satu minggu. Setiap melakukan latihan diperlukan 3 tahap yaitu:

Pemanasan dengan diiringi musik selama 5 menit

$>$ Latihan inti selama 40 menit

$>$ Pendinginan dengan diiringi musik menurunkan intensitas perlahan-lahan selama 5 menit.

b. Pengukuran Indeks Massa Tubuh

Pengukuran Indeks Massa Tubuh (Body Mass Index) dilakukan dengan mengukur Berat Badan (Kilogram) dan Tinggi Badan (meter)

$$
B M I=\frac{(\text { weight in kilograms) }}{\text { height in meters }^{2}}
$$

c. Pemeriksaan Kolesterol total.

Pemeriksaan total kolesterol dilakukan dengan menggunakan hematology analizer. Prosedur pemeriksaan dengan mengikuti prosedur yang sudah ditetapkan. Darah dimasukkan ke dalam sentrifugator. Selanjutnya darah disentrifus selama 3 menit dengan kecepatan $4000 \mathrm{rpm}$ sampai terpisah antara serum dengan plasma pada sampel tersebut. Dipipet serum dengan menggunakan pipet automatic sebanyak $50 \mu \mathrm{L}$ kemudian masukkan kedalam cup serum. Ditambahkan reagen kolesterol $1000 \mu \mathrm{l}$ dengan menggunakan mikropipet dan dibaca kadar kolesterol total dengan menggunakan ABX Pentra 400.

7. Analisis Data

Analisis yang digunakan dalam penelitian ini yaitu uji t dua sampel berpasangan (Paired Sample T-Test) Uji analisis statistik dengan Uji t dua sampel berpasangan (Paired Sample T-Test) bertujuan untuk melihat adanya perbedaan antara variable bebas (pre-test dan post-test) terhadap varibel terikat. Analisis data yang digunakan dalam penelitian ini adalah menggunakan uji-t dengan taraf signifikansi $(a<0,05)$, dengan langkah-langkah uji normalitas dan uji homogenitas sebagai syarat untuk uji statistik t. Pengujian semua data menggunakan aplikasi Statistic Packet for Sosial Science (SPSS versi 22.0). 


\section{HASIL DAN PEMBAHASAN PENELITIAN}

\section{HASIL PENELITIAN}

a. Karakteristik subyek

Subyek penelitian berjumlah 10 orang yang merupakan pegawai Universitas Terbuka berusia 18-25 tahun, berbadan sehat, IMT $\geq 25$, baru pertama kali mengikuti senam aerobik. Karakteristik subyek dapat dilihat pada tabel 1.

\section{Tabel 1.}

Karakteristik subjek penelitian

\begin{tabular}{|r|c|c|c|c|}
\hline \multicolumn{1}{|l|}{ No } & Variabel & $\mathrm{n}$ & Pretest & Postest \\
\hline 1. & BB $(\mathrm{kg})$ & 10 & $76,00 \pm 1,82$ & $61,57 \pm 1,27$ \\
\hline 2. & TB $(\mathrm{m})$ & 10 & $1,57 \pm, 02$ & $1,57 \pm, 02$ \\
\hline 3. & IMT $\left(\mathrm{kg} / \mathrm{m}^{2}\right)$ & 10 & $30,61 \pm, 44$ & $24,81 \pm, 90$ \\
\hline
\end{tabular}

Hasil uji normalitas dan homogenitas data berat badan dan IMT sebelum dan setelah melakukan latihan aerobik selama satu bulan menunjukkan bahwa data terdistribusi normal dan homogen ( $p>0,05)$. Hasil uji statistik dengan menggunakan uji t dua sampel berpasangan (Paired Sample T-Test) diperoleh nilai $\mathrm{p}=0,000(\mathrm{p}<0,05)$ yang menunjukkan terdapat perbedaan berat badan dan IMT sebelum dan setelah melakukan latihan aerobik dengan intensitas sedang selama satu bulan pada pegawai wanita obesitas di Universitas Terbuka Medan

b. Kadar kolesterol total

Kadar kolesterol total sebelum dan setelah melakukan latihan aerobik selama satu bulan dapat dilihat pada gambar 1 .

Hasil uji statistik data kolesterol total sebelum dan setelah melakukan senam aerobik diperoleh data terdistribusi normal dan homogen $(p>0,05)$. Hasil uji statistik dengan menggunakan uji t dua sampel berpasangan (Paired Sample T-Test) diperoleh nilai $\mathrm{p}=0,000(\mathrm{p}<0,05)$ yang menunjukkan terdapat perbedaan kadar kolsterol total sebelum dan setelah melakukan senam aerobik dengan intensitas sedang selama satu bulan pada pegawai wanita obesitas di Universitas Terbuka Medan. Penurunan kadar kolesterol total setelah senam aerobik adalah sebesar 19,39\%. 


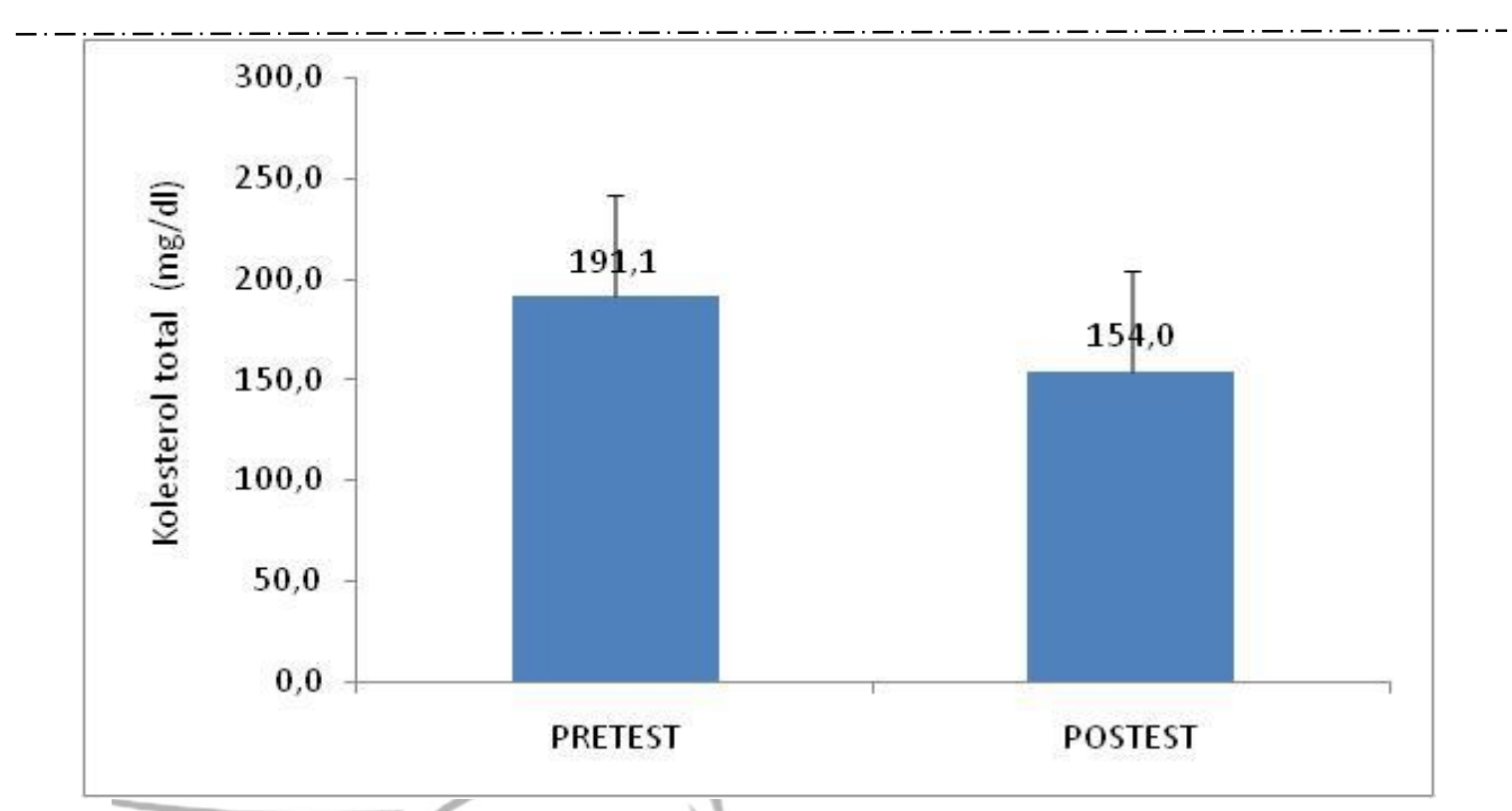

Gambar 1. Kadar kolesterol total sebelum dan setelah melakukan senam aerobik. Data adalah rerata $\pm S D, n=10, p<0,05$

\section{PEMBAHASAN PENELITIAN}

a. IMT sebelum dan sesudah intervensi

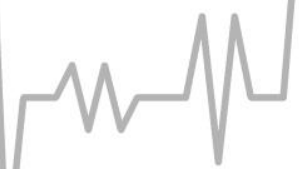

Terdapat penurunan yang bermakna antara rerata IMT subyek sebelum dan sesudah intervensi, yaitu $30,61 \mathrm{~kg} / \mathrm{m} 2$ turun menjadi $24,81 \mathrm{~kg} / \mathrm{m} 2$ atau terjadi penurunan sebesar 18,94\% seperti ditunjukkan pada gambar 2 .

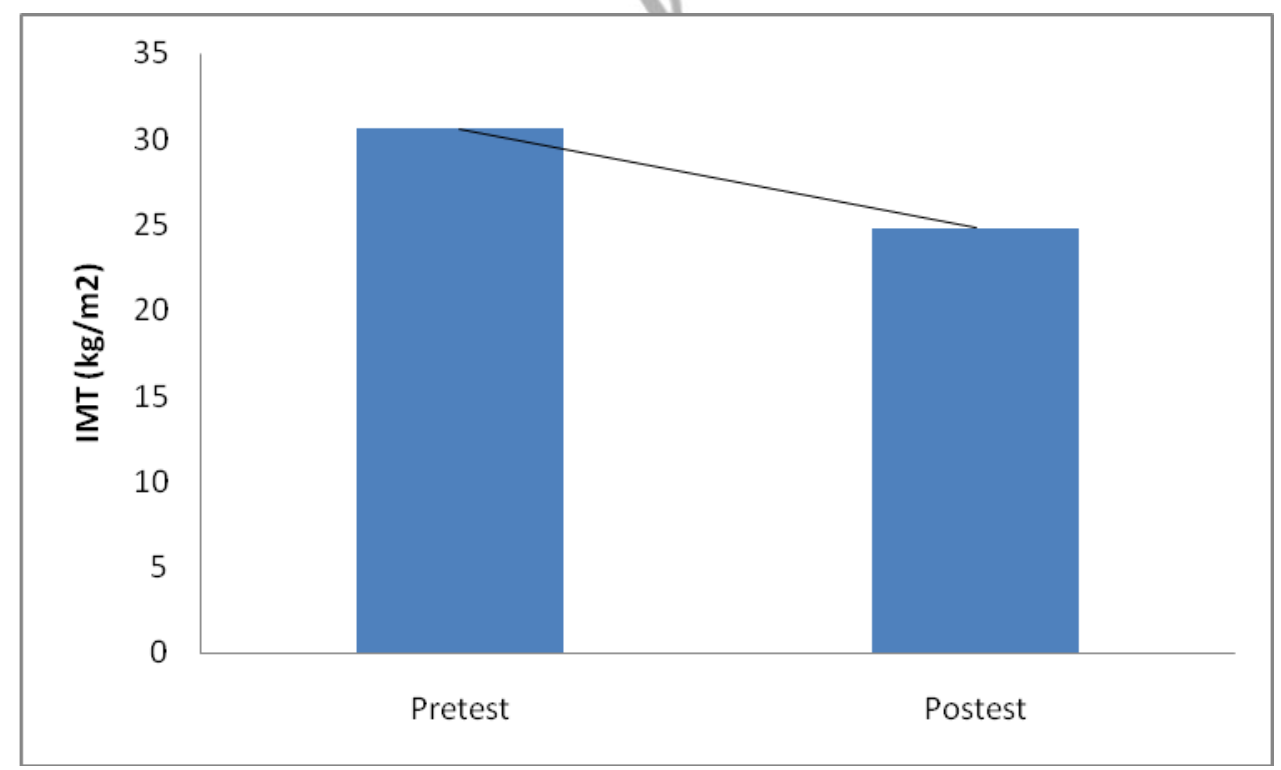

Gambar 2. Perubahan kadar IMT sebelum dan setelah melakukan senam aerobik. Data adalah rerata $\pm S D, n=10, \mathrm{p}<0,05$. 


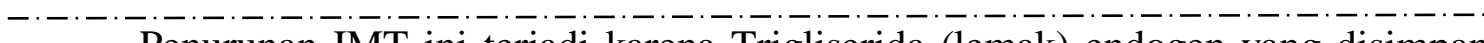

Penurunan IMT ini terjadi karena Trigliserida (lemak) endogen yang disimpan dalam jaringan adiposa (jaringan lemak) dan otot adalah merupakan sumber bahan bakar yang penting untuk keaktifan otot selama latihan. Menurut (Mora, 2000) intensitas latihan yang moderat akan menyebabkan proses lipolisis (trigliserida menjadi asam lemak) meningkat 2-3 kali lipat, dimana asam lemak yang dilepaskan akan dibawa darah ke otot skelet. Akibat proses lipolisis yang meningkat maka mengakibatkan penurunan massa jaringan lemak dari pada massa jaringan otot. Penurunan massa jaringan lemak akan mengakibatkan penurunan persentase lemak tubuh dan Berat Badan sehingga IMT juga turun karena IMT merupakan hasil dari Berat Badan dalam kilogram dibagi dengan kuadrat tinggi badan dalam meter $\left(\mathrm{kg} / \mathrm{m}^{2}\right)$. Hasil penelitian ini didukung oleh penelitian yang dilakukan di Australia terhadap 19 remaja obes yang diberi intervensi latihan sirkuit dengan melakukan latihan dengan menggunakan ergometer sepeda dan latihan ketahanan selama 8 minggu, dengan frekuensi latihan 3 kali seminggu dan durasi 1 jam yang telah terbukti memperbaiki kapasitas fungsional, ketahanan otot, dan komposisi tubuh, serta lebih jauh, dapat memperbaiki profil lemak darah.

b. Kadar Kolesterol total sebelum dan sesudah intervensi

Hasil penelitian menunjukkan senam aerobok intensitas sedag dapat menurunkan kadar kolesterol total sebesar 19,39\%. Turunnya kadar kolesterol akibat senam aerobik intensitas sedang adalah akibat senam aerobik pada intensitas sedang dalam waktu yang relatif lama dapat menyebabkan asam lemak dirubah menjadi sumber energi, sehingga dapat memperkecil peluang sintesis inti sterol, maka kolesterol tidak dapat terbentuk secara berlebihan (George et al., 2006).

Pada latihan intensitas sedang dengan durasi latihan lebih dari 1 jam secara kontinyu terjadi proses degradasi lemak. Keadaan ini sebagian besar disebabkan oleh terjadinya pelepasan epinefrin dan norepinefrin oleh medula adrenal selama beraktivitas. Kedua hormon ini secara langsung mengaktifkan enzim lipase yang menyebabkan pemecahan trigliserida yang sangat cepat dan mobilisasi asam lemak. Pada saat melakukan aktivitas fisik yang relatif lama terjadi peningkatan asam lemak di dalam darah yang merupakan bahan baku untuk pembentukan energi di dalam otot pada waktu melakukan aktivitas fisik. Konsentrasi asam lemak bebas dalam darah seseorang yang sedang beraktivitas dapat meningkat sampai delapan kali lipat. Asam lemak ini 
akan ditransfer ke dalam otot sebagai sumber energi. Mekanisme inilah yang dapat menerangkan terjadinya penurunan LDL kolesterol, oleh karena bahan baku utama pembentukan LDL kolesterol berasal dari trigliserida (Guyton et al, 2007).

Latihan intensitas sedang dengan durasi yang tepat akan menggunakan energi yang berasal dari lemak. Hasil penelitian pada laki-laki berusia 18 tahun dapat meningkatkan kadar HDL kolesterol sebesar $9 \%$, menurunkan trigliserida $11 \%$. Hasil penelitian lainnya menemukan bahwa latihan aerobik pada wanita dapat menurunkan kolesterol total sebesar $19 \%$, LDL kolesterol sebesar $11 \%$, trigliserida $8 \%$ (George AK et al, 2009).

\section{KESIMPULAN}

Kesimpulan penelitian adalah senam aerobik intensitas sedang dapat menurunkan IMT dan kadar total kolesterol pada wanita penderita obesitas.

\section{Daftar Pustaka}

Ayu,A. M ,., Mutalazimah, Herawaty,I (2017). Hubungan Frekuensi Senam Aerobik Dan Asupan Kolesterol Terhadap Kadar Kolesterol Darah Wanita Usia Subur Di Pusat Kebugaran Syariah Agung Fitnes Makamhaji. Jurnal kesehatan. Vol. 10, No. 2. Hal 74-82

Departemen Kesehatan RI. 2013. Laporan Hasil Riset Kesehatan Dasar (RIDENKES) Nasional. Badan Penelitian dan Pengembangan.

Ecol, J. 2008. A Study of Correlation Between Lipid Profile and Body Mass Index (BMI) in Patient With Diabetes Melitus. http://www.krepublisheers.com/02jurnal/ (Diakses pada tanggal 4 Desember 2016 pukul 13.45).

George A, Kelley, DA, FACSM, Kristi, Barry Franklin PhD. 2006. Aerobic Exercise and Lipids and Lipoprotein in Patients With Cardiovascular Disease.

Guyton A.C. and J.E. Hall 2007. Buku Ajar Fisiologi Kedokteran. Edisi 9. Jakarta: EGC.

Laurentia, Y.S. 2012. Dislipidemia pada Obesitas dan Tidak Obesitas di RSUP Dr. Kariadi dan Laboratorium Klinik Swasta di Semarang. Jurnal Fakultas Kedokteran Universitas Diponogoro. Hal:3

Mamiitoho, R.F., Sapulete,I.M., Pengemanan, D.H.C. (2016). Pengaruh senam lansia terhadap kadar kolesterol total pada lansia di BPLU Senja Cerah Manado. Jurnal e-Biomedik (eBm), Volume 4, Nomor 1. Hal 110-115

Pratiwi, Yunita, S. 2010. Diabetes Melitus pada Obesitas. The Indonesia Journal of Health Science. 1(1).

Saeed, E.; Ali, R.; Jalal-ud-din, M.; Saeed, A.; Jadoon, R.J.; Moiz, M. Hypercholesterolemia in patients of ischemic stroke. J. Ayub. Med. Coll. Abbottabad 2015, 27, 637-639. [PubMed]

Saeed,E, Ali, R, Jalaluddin, M. Saeed, A, Jadoon, R.J, Moiz, M. Hypercholesterolemia in patients of ischemic stroke. J. Ayub. Med. Coll. Abbottabad 2015, 27, 637-639. [PubMed] 
Shah, S.Z.A., Devrajani, B.R., Devrajani, T., Bibi, I. 2008. Frequency of Dyslipidemia in Obese versus Non- Obese in Relation to Body Mass Index (BMI), Waist Hip Ratio (WHR) and Waist Circumference (WC). Pakistan Journal of Science. 62(1):27-31.

Silva, D.A.S, Petroski,E.L. (2014). Effects Of Aerobic Exercise On The Body Composition And Lipid Profile Of Overweight Adolescents. Rev. Bras. Ciênc. Esporte, Florianópolis, v. 36, n. 2, p. 295-309

Suhardiansyah. A.B., Kinanti,R.G, Raharjo,S. (2015). Pengaruh Senam Aerobik Intensitas Ringan Dan Sedang Terhadap Kadar Ldl Pada Perempuan Obes Di Kota Batu. Jurnal Sport Science, Vol 6. No 2. hlm.87-98

WHO (2018) | Obesity and overweight [Internet]. http://www.who.int/en/newsroom/fact-sheets/detail/obesity-and-overweight

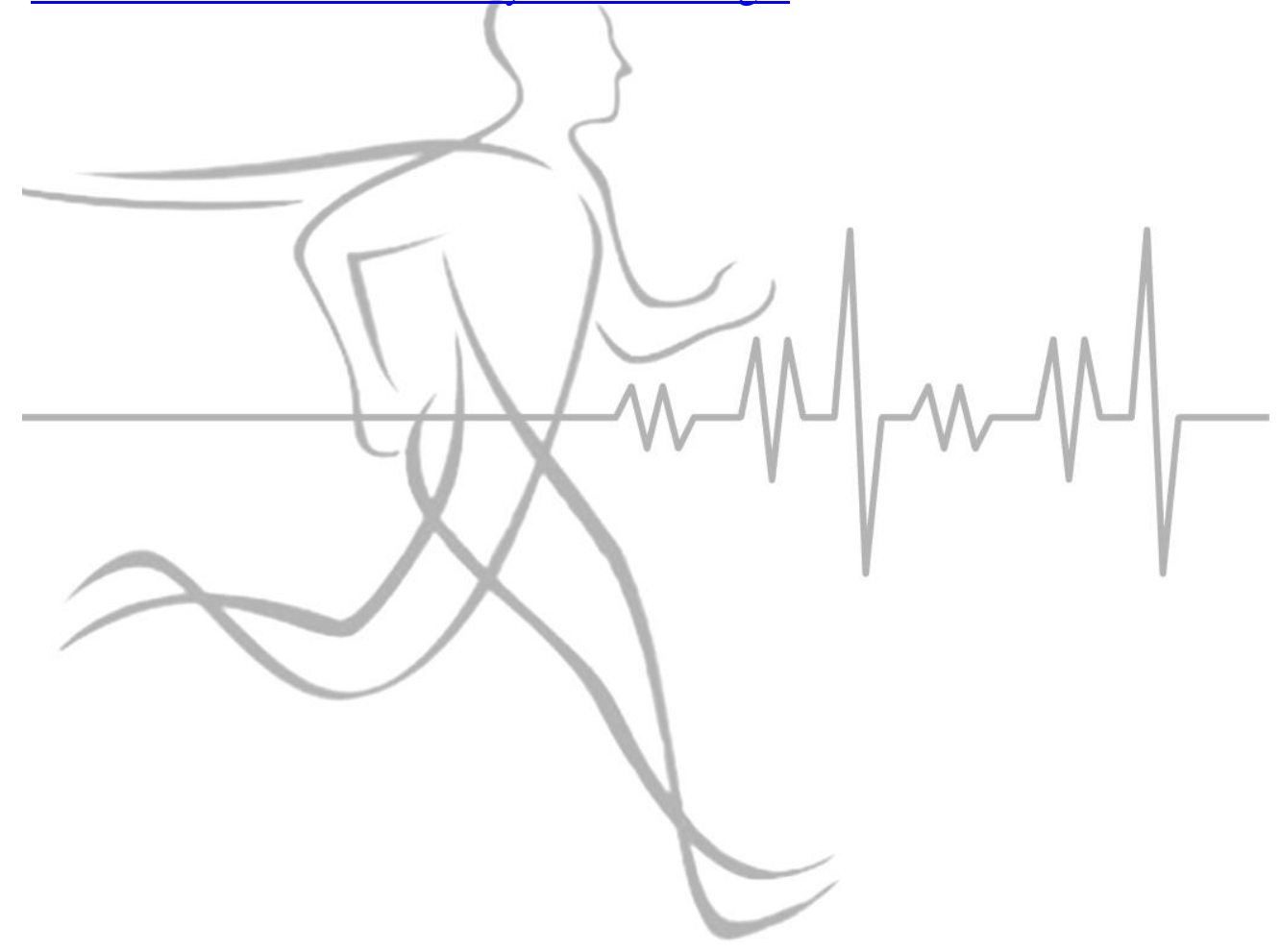

